\title{
Preparation of hippurate-zinc layered hydroxide nanohybrid and its synergistic effect with tamoxifen on HepG2 cell lines
}

This article was published in the following Dove Press journal:

International Journal of Nanomedicine

30 November 2011

Number of times this article has been viewed

\author{
Samer Hasan Hussein Al Ali \\ Mothanna Al-Qubaisi² \\ Mohd Zobir Hussein 1,3 \\ Zulkarnain Zainal' \\ Muhammad Nazrul Hakim ${ }^{4}$ \\ 'Department of Chemistry, Faculty \\ of Science; ${ }^{2}$ Department of Cell \\ and Molecular Biology, Faculty of \\ Biotechnology and Biomolecular \\ Science; ${ }^{3}$ Advanced Materials and \\ Nanotechnology Laboratory, Institute \\ of Advanced Technology; ${ }^{4}$ Department \\ of Biomedical Science, Faculty \\ of Medicine and Health Science, \\ Universiti Putra Malaysia, Serdang, \\ Selangor, Malaysia
}

Background: A new simple preparation method for a hippurate-intercalated zinc-layered hydroxide (ZLH) nanohybrid has been established, which does not need an anion-exchange procedure to intercalate the hippurate anion into ZLH interlayers.

Methods: The hippuric acid nanohybrid (HAN) was prepared by direct reaction of an aqueous suspension of zinc oxide with a solution of hippuric acid via a one-step method.

Results: The basal spacing of the nanohybrid was $21.3 \AA$, indicating that the hippurate anion was successfully intercalated into the interlayer space of ZLH, and arranged in a monolayer fashion with the carboxylate group pointing toward the ZLH inorganic interlayers. A Fourier transform infrared study confirmed the formation of the nanohybrid, while thermogravimetry and differential thermogravimetry analyses showed that the thermal stability of the nanohybrid was markedly enhanced. The loading of hippurate in the nanohybrid was estimated to be about $38.7 \%(\mathrm{w} / \mathrm{w})$, and the release of hippurate from the nanohybrid was of a controlled manner, and therefore the resulting material was suitable for use as a controlled-release formulation. HAN has synergistic properties with tamoxifen toward a HepG2 cell line, with an $\mathrm{IC}_{50}$ value of 0.35 compared with hippurate. In the antiproliferative assay, the ratio of viable cells account for cells treated by the combination tamoxifen with HAN to untreated cells was sharply reduced from $66 \%$ to $13 \%$ after 24 and 72 hours, respectively.

Conclusion: The release of hippuric acid anions from HAN occurred in a controlled manner, and the resulting material is suitable for a controlled-release formulation.

Keywords: hippuric acid, nanohybrids, zinc oxide, zinc-layered hydroxide, synergistic effect

\section{Introduction}

Discovered in 1824, brucite is the natural mineral form of magnesium hydroxide. The magnesium ions with a $(2+)$ charge are centered to six octahedrally hydroxides with a (1-) charge. Each hydroxide is bonded to three magnesium atoms, resulting in neutral layers that interact with each other by weak forces. ${ }^{1}$

Hydrotalcite and hydrotalcite-like materials are derived from the brucite structure, and can be described by the formula $\mathrm{Mg}_{6} \mathrm{Al}_{2}\left(\mathrm{CO}_{3}\right)(\mathrm{OH})_{16} \cdot 4 \mathrm{H}_{2} \mathrm{O}$, formed by isomorphous substitution of the $\mathrm{Mg}^{2+}$ with $\mathrm{Al}^{3+}$ and creating layers with a positive charge. These charges are counter balanced by carbonate anions. ${ }^{1}$ Substitution of the $\mathrm{Mg}^{2+}$ and/or $\mathrm{Al}^{3+}$ in hydrotalcite by $\mathrm{Zn}^{2+}, \mathrm{Co}^{2+}, \mathrm{Mn}^{2+}, \mathrm{Cu}^{2+}, \mathrm{Cr}^{3+}, \mathrm{Co}^{3+}$, and $\mathrm{Fe}^{3+}$ can result in formation of hydrotalcite-like materials with exchangeable counter anions, such as $\mathrm{OH}^{-}, \mathrm{Cl}^{-}$, $\mathrm{NO}_{3}{ }^{-}$, and $\mathrm{CO}_{3}{ }^{2-}$, and with the general formula $\left[\mathrm{M}_{1-x}^{2+} \mathrm{M}_{x}^{3+}(\mathrm{OH})_{2}\right]^{X+}\left(\mathrm{A}^{\mathrm{m}-}\right)_{x / m} \cdot n \mathrm{H}_{2} \mathrm{O}$ where $\mathrm{M}^{2+}$ refers to divalent cations, $\mathrm{M}^{3+}$ refers to trivalent cations, and $\mathrm{A}^{\mathrm{m}-}$ refers to the exchangeable anion with a charge $(-\mathrm{m}){ }^{2,3}$
Correspondence: Mohd Zobir Hussein

Department of Chemistry,

Faculty of Science, Universiti

Putra Malaysia, Serdang,

Selangor, Malaysia

Tel +60389466801

Fax +60389435380

Email mzobir@science.upm.my 
A zinc-layered hydroxide (ZLH) structure is derived from brucite, in which only zinc and hydroxyl constitute the inorganic layers. These can be classified into two types, ie, Type I, with an empirical formula of $\mathrm{Zn}_{2}(\mathrm{OH})_{2}\left(\mathrm{NO}_{3}\right)_{2} \cdot 2 \mathrm{H}_{2} \mathrm{O}$, in which zinc is coordinated octahedrally with six hydroxide groups, and the nitrate anion interlayers are directly coordinated to the zinc, ${ }^{4}$ and Type II, containing two groups, in both of which one quarter of the octahedral zinc cations are displaced from the main layer to tetrahedral sites located above and below each empty octahedron. Three vertices of the tetrahedron are occupied by hydroxides shared with the octahedral sheet, the apex is occupied by water molecules in Group IIa and takes on a $\mathrm{Zn}_{5}(\mathrm{OH})_{8}\left(\mathrm{NO}_{3}\right)_{2} \cdot 2 \mathrm{H}_{2} \mathrm{O}$ structure. The nitrate ions are located between the layers and are surrounded by water molecules. ${ }^{4,5}$ In Group IIb, the apex is occupied by nitrate ions which coordinate directly with the zinc tetrahedron and take on a $\mathrm{Zn}_{5}(\mathrm{OH})_{8}\left(\mathrm{NO}_{3}\right)_{2}$ structure. ${ }^{4}$ This means that the anions are coordinated directly with a zinc tetrahedron.

Inorganic nanomaterials have attracted considerable attention due to their versatile biological applications. ${ }^{6,7}$ There have been a number of recent reports of ZLH compounds with beneficial intercalated organic anions, such as 4-(2,4-dichlorophenoxybutyrate), ${ }^{8}$ orange $\mathrm{G},{ }^{9,10}$ benzoic acid, ${ }^{11}$ succinic acid, glutaric acid and adipic acid, ${ }^{12}$ sodium heptanoate, ${ }^{13}$ organometallic compounds, such as iron(III) porphyrin, ${ }^{14}$ and complex compounds, such as oxalatooxoniobate complex..$^{15}$

Hippuric acid (N-benzyl glycin) is obtained from the urine of domestic animals and humans. It is synthesized in the liver as a derivative of glycin, a metabolite of benzoic acid urinary excretion. ${ }^{16}$ Biological investigation of hippuric acid shows that it has limited antimicrobial activity at acidic $\mathrm{pH}$ values ${ }^{17}$ and has synergistic potentiating actions on tumor cell lines when mixed with other components. ${ }^{18}$

Previous work has also shown that hippuric acid can be intercalated into $\mathrm{Zn}-\mathrm{Al}_{-} \mathrm{NO}_{3}$ layered double hydroxide by ion exchange between the nitrate group in the interlayer and the hippurate anion in solution. ${ }^{19}$ This study showed that during the intercalation process, the nitrate group was not completely replaced by the anion in solution, which may have an effect on loading. Recently, new studies have reported that intercalation of anions into ZLH could be directly accomplished using zinc oxide as the starting material. ${ }^{20}$ This method does not need an anion-exchange reaction to incorporate anions into the ZLH interlayers. Due to the relatively few studies reported using this method, the main purpose of this work is to intercalate the hippuric acid anion into ZLH by direct reaction of zinc oxide with the anion in aqueous solution.

\section{Materials and methods Materials}

Hippuric acid (98\% purity) was purchased from Merck (Darmstadt, Germany) and used as received. Zinc oxide of American Chemical Society reagent grade was purchased from Fisher Scientific (Waltham, MA), and dimethyl sulfoxide was purchased from Ajax Finechen (Sydney, Australia) and used without further purification. Phosphate-buffered solution was purchased from Sigma-Aldrich (St Louis, MO). Deionized water was used in all the experiments.

\section{Preparation of HAN}

The hippuric acid nanohybrid (HAN) was synthesized by the direct method using zinc oxide as the starting material as reported previously, ${ }^{20}$ with minor modification. Hippuric acid solution $(0.2$ M) was prepared by dissolving $1.8 \mathrm{~g}$ of hippuric acid in $20 \mathrm{~mL}$ of dimethyl sulfoxide and adjusting to $50 \mathrm{~mL}$ by addition of deionized water. The zinc oxide powder $(0.2 \mathrm{~g})$ was suspended in water $(50 \mathrm{~mL})$. Hippuric acid solution was added dropwise to the zinc oxide suspension, with vigorous stirring until the addition was complete and the solution became clear. After adjusting the $\mathrm{pH}$ to 7.9 using an aqueous solution of $\mathrm{NaOH}(0.5 \mathrm{~mol} / \mathrm{L})$, the resulting solution was magnetically stirred for 18 hours at $70^{\circ} \mathrm{C}$. The white precipitate was centrifuged, thoroughly washed by deionized water, dried in an oven at $60^{\circ} \mathrm{C}$ overnight, and kept in a sample bottle for further use and characterization.

\section{MTT cytotoxicity assay}

A human liver carcinoma cell line (HepG2) was seeded into 96-well plates and kept at $5 \% \mathrm{CO}_{2}$ and $37^{\circ} \mathrm{C}$ for 24 hours, at a cell density of $50 \%$ confluence, and the cells were then treated with tamoxifen alone and an equivalent cytostatic mixture of either hippuric acid or HAN. After 72 hours of incubation, $20 \mu \mathrm{L}$ of MTT solution $(5 \mathrm{mg} / \mathrm{mL})$ was added to each well and incubated for 4 hours. The microplates were turned swiftly to discard the medium, and the formazan precipitate was dissolved in $10 \%$ sodium dodecyl sulfate in dimethyl sulfoxide containing $0.6 \%$ acetic acid. The microplates were then gently shaken in the dark for 30 minutes, and absorbance at 570 and $630 \mathrm{~nm}$ (background) was measured with a microtiter plate reader. All experiments were carried out in triplicate. $\mathrm{The} \mathrm{IC}_{50}$ was generated from the dose-response curves for the cell line.

\section{Antiproliferation assay}

HepG2 cells were first seeded in six-well plates when they reached $40-60 \%$ confluence. After incubation for 24 hours for cell attachment, exponentially growing cells were exposed to tamoxifen $(5 \mu \mathrm{g} / \mathrm{mL})$ alone, and its combination with hippuric 
acid $(5 \mu \mathrm{g} / \mathrm{mL})$ or HAN $(5 \mu \mathrm{g} / \mathrm{mL})$. The plates were incubated at $37^{\circ} \mathrm{C}, 5 \% \mathrm{CO}_{2}$, for 24,48 , and 72 hours. After incubation, the media was aspirated off, washed with cold phosphatebuffered saline (PBS) (to get rid of the dead cells) and replaced with $1 \mathrm{~mL} 0.05 \%(2 \mathrm{mg} / \mathrm{mL})$ trypsin-EDTA. The plates were incubated at $37^{\circ} \mathrm{C}$ for $10-15$ minutes, until the majority of the cells had lifted off. The cells were harvested then. The cell suspension was centrifuged at $1000 \mathrm{rpm}$ for 10 minutes, and the supernatant discarded. Twenty microliters of cell suspension was mixed with $20 \mu \mathrm{L}$ of $0.4 \%$ trypan blue solution. Cells were resuspended and dye-excluding viable cells were microscopically counted using a hemocytometer.

\section{Characterization}

Powder X-ray diffraction patterns were recorded with a Shimadzu XRD-6000 instrument (Shimazdu, Tokyo, Japan) using $\mathrm{CuK}_{\alpha}$ radiation $(\lambda=1.5418 \AA)$ and a dwell time of 4 degrees per minute. Fourier transform infrared spectra were recorded over the $400-4000 \mathrm{~cm}^{-1}$ range on a Perkin-Elmer (Boston, MA) $1752 \mathrm{X}$ spectrophotometer, using an approximately $1 \%$ sample in $100 \mathrm{mg}$ of spectroscopic grade potassium bromide, the pellets being pressed at 10 tons. The carbon, hydrogen, and nitrogen content in the nanohybrid was analyzed on a CHNS-932 (LECO Instruments, St Joseph, MI). The chemical composition of the samples was analyzed for zinc ions by inductively coupled plasma atomic emission spectrometry using a Perkin-Elmer spectrophotometer model Optima 2000DV (Perkin-Elmer) under standard conditions. Thermogravimetry and differential thermogravimetry analyses were performed in $150 \mu \mathrm{L}$ alumina crucibles using a Metter-Toledo instrument (Longview, WA) at a heating rate of 10 degrees per minute in the range of $20^{\circ} \mathrm{C}-1000^{\circ} \mathrm{C}$. Surface characterization of the materials was carried out using a nitrogen gas adsorption-desorption technique at $77 \mathrm{~K}$ with a Micromeritics ASAP2000 (Norcross, GA). The sample was degassed in an evacuated heated chamber at $100^{\circ} \mathrm{C}$ overnight. The surface morphology of the samples was observed by scanning electron microscopy using a JOEL JSM-6400 (Joel Inc, Peabody, MA), and an ultraviolet-visible spectrophotometer was used for elucidation of the optical properties.

\section{Release of hippuric acid from HAN}

The release of hippuric acid from the nanohybrid into media was accomplished using an $0.08 \mathrm{M}$ aqueous solution of $\mathrm{Na}_{2} \mathrm{CO}_{3}^{21}$ and a phosphate-buffered solution of $\mathrm{pH} 4.8$ and $7.4^{22}$ at room temperature. The phosphate-buffered solution contains a number of anions, such as $\mathrm{Cl}^{-}$, monobasic phosphate $\mathrm{H}_{2} \mathrm{PO}_{4}^{-}$, and dibasic phosphate $\mathrm{HPO}_{4}^{2-}$. About $85 \mathrm{mg}$

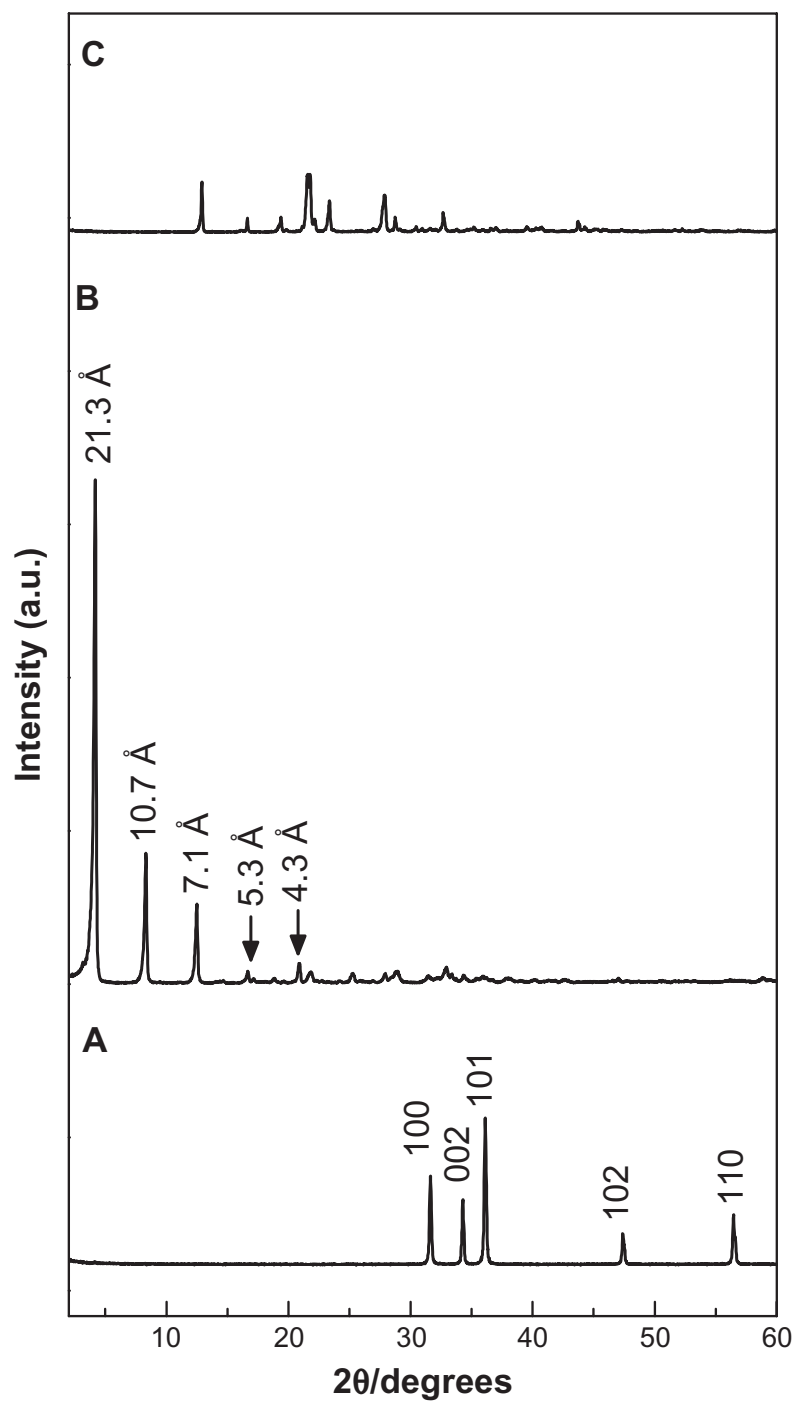

Figure I Powder X-ray diffraction patterns of (A) $\mathrm{ZnO}$, (B) HAN, and (C) HA Abbreviations: $\mathrm{ZnO}$, zinc oxide; $\mathrm{HAN}$, hippuric acid nanohybrid; $\mathrm{HA}$, hippuric acid.

of HAN was added to $500 \mathrm{~mL}$ of the media. The accumulated amount of hippuric released into the solution was measured at $\lambda_{\max }=228 \mathrm{~nm}$ using a Perkin Elmer ultraviolet-visible spectrophotometer, model Lambda 35. To compare the release rate of hippuric acid from HAN with that from the physical mixture of hippuric acid and pristine ZLH (prepared for this purpose), ${ }^{23} 0.6 \mathrm{mg}$ of the physical mixture of hippuric acid $(0.24 \mathrm{mg})$ and ZLH $(0.36 \mathrm{mg})$ was used to perform the same hippuric acid release experiments, as stated earlier.

\section{Results and discussion Powder X-ray diffraction and structural model}

Figure $1 \mathrm{~A}, \mathrm{~B}$, and $\mathrm{C}$ show the powder X-ray diffraction patterns for zinc oxide, HAN, and hippuric acid, respectively. As reported in the literature, the zinc hydroxide nitrate has a 
sharp reflection peak with d spacing of $9.74 \AA$ at $2 \theta=9.12$ due to the 200 plane of the monoclinic structure. ${ }^{23}$ After the intercalation process, the basal distance increased by more than $9.74 \AA$. The expansion is due to the spatial orientation and the dimensions of the intercalated compounds. ${ }^{23}$ Figure 1A shows that zinc oxide has five intense peaks between $30^{\circ}$ and $60^{\circ}$, corresponding to diffractions due to the $100,002,101$, 102 , and 110 planes. The X-ray diffraction patterns of HAN are shown in Figure 1B, without any reflections of the zinc oxide phase and at same time displaying a sharp intense peak at a low $2 \theta$ angle, with $d$ spacing of $21.3 \AA$, which indicate successful intercalation of the hippurate anions into the interlayers of zinc-layered hydroxide. In addition, Figure 1B shows another four harmonics at $2 \theta=8.32^{\circ}, 12.50^{\circ}, 16.68^{\circ}$, and $20.84^{\circ}$, with d values of $10.7,7.1,5.3$, and $4.3 \AA$, respectively, resulting in an average $d$ value of $21.3 \AA$.

The mechanism of formation of HAN synthesized by direct reaction of zinc oxide in an aqueous environment can be described as follows. ${ }^{8,24}$ Thin layers of zinc hydroxide, ie, $\mathrm{Zn}(\mathrm{OH})_{2}$, form on the surface of the solid particles as a result of hydrolyzed zinc oxide in an aqueous environment; $\mathrm{Zn}^{2+}$ species form by dissociation of $\mathrm{Zn}(\mathrm{OH})_{2}$ in a solution-solid interface; and $\mathrm{Zn}^{2+}$ ions react with hydroxyls, hippurate anions, and water in solution to form the layered HAN compound.

Figure 2A shows the three-dimensional molecular size of hippuric acid estimated by Chemoffice software (Cambridge, MA). The long and short axes and molecular thickness of hippuric acid are 11.3, 7.4, and 4.1 $\AA$, respectively. Based on the average basal spacing of $21.3 \AA$ for HAN observed by $\mathrm{X}$-ray diffraction, and subtracting the thickness of the brucite layer $(4.8 \AA)$ and $2.6 \AA$ for each zinc tetrahedron, ${ }^{5}$ the gallery height is calculated to be $11.3 \AA$, which is identical to the longest axis of hippuric acid. Therefore, it is proposed that hippurate molecules are arranged in a vertical monolayer, as shown in Figure 2B.

\section{Fourier transform infrared spectroscopy}

The Fourier transform infrared spectra for pure hippuric acid and HAN are shown in Figure 3. The main Fourier transform infrared absorption bands for hippuric acid and HAN are listed in Table 1. Figure 3A shows intense sharp bands at $3342 \mathrm{~cm}^{-1}$ and $3072 \mathrm{~cm}^{-1}$ which are assigned to the $\mathrm{N}-\mathrm{H}$ stretching mode. ${ }^{25} \mathrm{~A}$ band at $2938 \mathrm{~cm}^{-1}$ can be attributed to $\mathrm{C}-\mathrm{H}$ stretching. ${ }^{26} \mathrm{An}$ intense sharp band at $1760 \mathrm{~cm}^{-1}$ and $1744 \mathrm{~cm}^{-1}$ is due to the $\mathrm{C}=\mathrm{O}$ stretching of $\mathrm{COOH} .{ }^{27}$ The bands at $1621 \mathrm{~cm}^{-1}$ and $1608 \mathrm{~cm}^{-1}$ are due to $\delta_{\mathrm{b}}(\mathrm{N}-\mathrm{H}) .{ }^{25}$ The band at $1558 \mathrm{~cm}^{-1}$ is due to a $\mathrm{C}=\mathrm{C}$ in the benzene ring. Other band assignments are shown in Table 1.

The Fourier transform infrared spectrum of HAN in Figure 3B shows similar bands, characteristic of pure hippuric acid. This indicates that the hippuric anions have been intercalated into the interlayer galleries of the ZLH. A broad absorption band at around $3427 \mathrm{~cm}^{-1}$ is assigned to $\mathrm{O}-\mathrm{H}$ stretching. ${ }^{28}$ The absence of the absorption bands at $1760 \mathrm{~cm}^{-1}$ and $1744 \mathrm{~cm}^{-1}$, which are due to a carboxylic group $(\mathrm{COOH})$, clearly indicates that the hydrogen ions in the hippuric acid molecules are removed and that the hippurate anion is attached to the positively charged inorganic ZLH interlayers. The asymmetric stretching of the carboxylate group between $1551 \mathrm{~cm}^{-1}$ and $1578 \mathrm{~cm}^{-1},{ }^{25,27,29}$ as well as the symmetric vibration at $1412 \mathrm{~cm}^{-1}$, confirm the intercalation of the hippurate, and the formation of HAN. Some of the bands are slightly shifted in position due to the interaction between hippurate anions as a host interlayer, as a result of the intercalation process that is shown in Table 1.
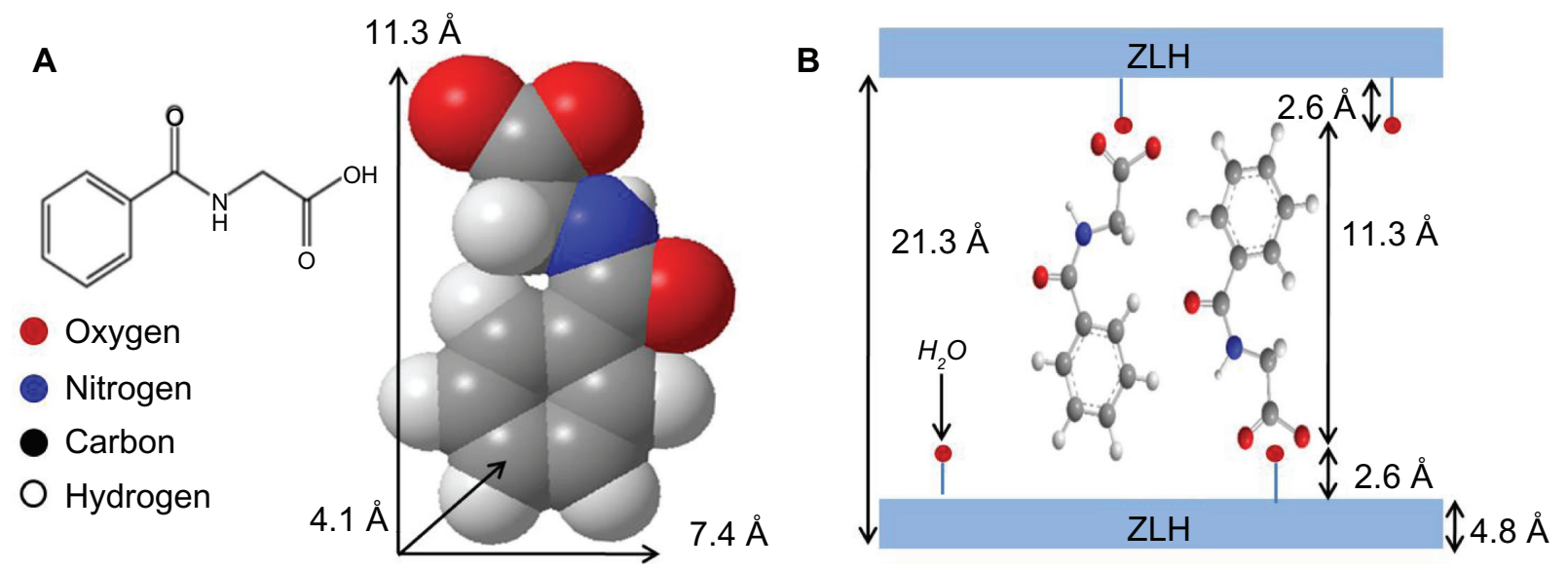

Figure 2 Molecular structure of HA and three-dimensional molecular size of (A) HA and (B) spatial orientation of hippuric acid in ZLH inorganic interlayers. Abbreviations: HA, hippuric acid; ZLH, zinc layered hydroxide. 


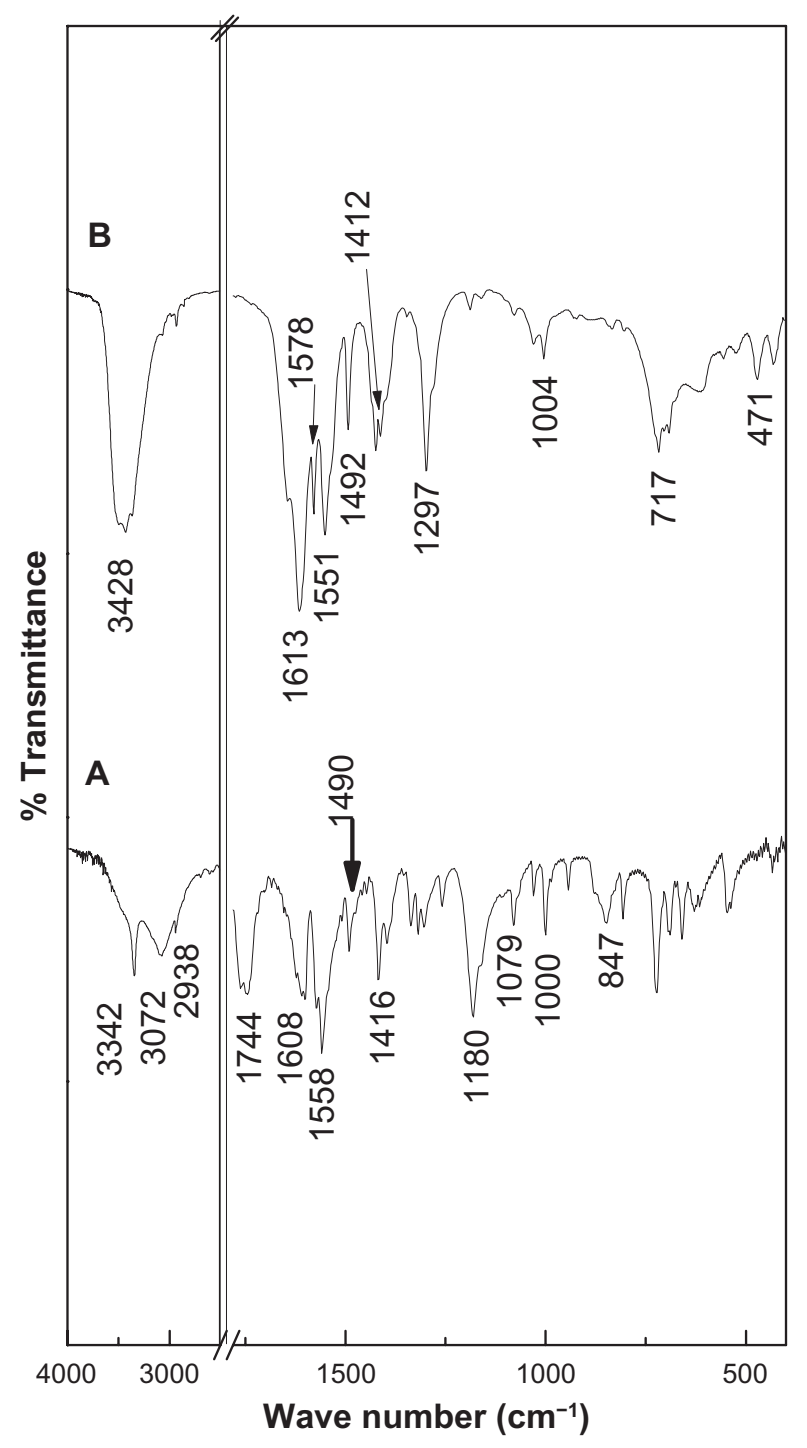

Figure 3 Fourier transform infrared spectra of (A) HA and (B) HAN. Abbreviations: HA, hippuric acid; HAN, hippuric acid nanohybrid.

\section{Thermal stability}

One of the most important physicochemical properties of the ZLH nanohybrid is its thermal stability. In the case of pure hippuric acid, the thermogravimetry and differential thermogravimetry analyses (Figure 4A) showed a single sharp weight loss starting at $188^{\circ} \mathrm{C}$, but no weight loss could be observed below this temperature. Hence the hippuric acid was found to be stable up to $188^{\circ} \mathrm{C}$. The nature of the weight loss illustrates volatilization rather than degradation ${ }^{26}$ with $81.5 \%$ weight loss occurring at $188^{\circ} \mathrm{C}-433^{\circ} \mathrm{C}$.

The thermal behavior of HAN (Figure 4B) shows five stages of weight loss between $51^{\circ} \mathrm{C}$ and $701^{\circ} \mathrm{C}$. The first and second weight loss steps between $51^{\circ} \mathrm{C}$ and $120^{\circ} \mathrm{C}$ and between $127^{\circ} \mathrm{C}$ and $180^{\circ} \mathrm{C}$ are attributed to the removal of surface physisorbed water molecules with $7.2 \%$ and
Table I Fourier transform infrared assignments for $\mathrm{HA}$ and HAN $^{25,27,30,31}$

\begin{tabular}{lll}
\hline Assignments & HA & HAN \\
\hline$v(\mathrm{O}-\mathrm{H})$ in the layer; $\mathrm{H}_{2} \mathrm{O}$ & - & 3428 \\
$v(\mathrm{~N}-\mathrm{H})$ & 3342 & - \\
$v(\mathrm{C}-\mathrm{H})$ & 3072 & \\
$v(\mathrm{C}=\mathrm{O})$ in $\mathrm{COOH}$ & 2938 & 2930 \\
& 1760 & - \\
$v_{\mathrm{as}}(\mathrm{COO}-)$ & 1744 & \\
$v_{\mathrm{s}}(\mathrm{COO})$ & - & $1578-1551$ \\
$\delta_{\mathrm{b}}(\mathrm{N}-\mathrm{H})$ & - & 1412 \\
& 1621 & 1613 \\
$\mathrm{C}-\mathrm{H}$ deformation & 1608 & \\
$\delta_{\mathrm{b}}(\mathrm{CH})$ & 1490 & 1492 \\
& 1336 & 1297 \\
$v(\mathrm{C}-\mathrm{C})$ & 1318 & \\
& 1304 & \\
$\delta_{\mathrm{b}}\left(\mathrm{CH}_{2}\right)$, in plane bend & 1258 & 922 \\
$\delta_{\mathrm{r}}\left(\mathrm{CH}_{2}\right)$ & 943 & 833 \\
& $85 \mathrm{I}$ & \\
$\delta_{\mathrm{b}}\left(\mathrm{COO}^{-}\right)$ & 1180 & 1187 \\
\hline
\end{tabular}

Abbreviations: HA, hippuric acid; HAN, hippuric acid nanohybrid.

intercalated structure water with $6.3 \%$ mass reduction, respectively. Correspondingly, the differential thermogravimetric curve shows two peaks at $101^{\circ} \mathrm{C}$ and $159^{\circ} \mathrm{C}$. The other stages of weight loss are due to dehydroxylation of the hydroxide layers and elimination and combustion of the hippurate anions, which are usually overlapping. ${ }^{32}$ Therefore, the stages between $251^{\circ} \mathrm{C}$ and $700^{\circ} \mathrm{C}$ are due to these thermal behaviors, with a total weight loss of $36.6 \%$. The differential thermogravimetric curve shows one peak at $607^{\circ} \mathrm{C}$, which corresponds to decomposition of the benzene ring. ${ }^{33}$ Table 2 shows the elemental analysis of HAN which contains $23.3 \%$ carbon, $3.5 \%$ hydrogen, and $3.1 \%$ nitrogen; the loading percentage of hippuric acid in the nanohybrid is $38.7 \%$. It should be noted that the temperature region in HAN is obviously higher than that of pure free hippuric acid, suggesting that the thermal stability of organic hippuric acid species in HAN is clearly enhanced due to the interaction between hippurate anions and the positively charged host, ie, ZLH.

\section{Optical properties}

Ultraviolet absorbance curves for hippuric acid and HAN are shown in Figure 5A. For hippuric acid, the absorption peaks are observed at $223 \mathrm{~nm}$ and $280 \mathrm{~nm}$, due to $\pi \rightarrow \pi *$ and $\mathrm{n} \rightarrow \pi *$ 

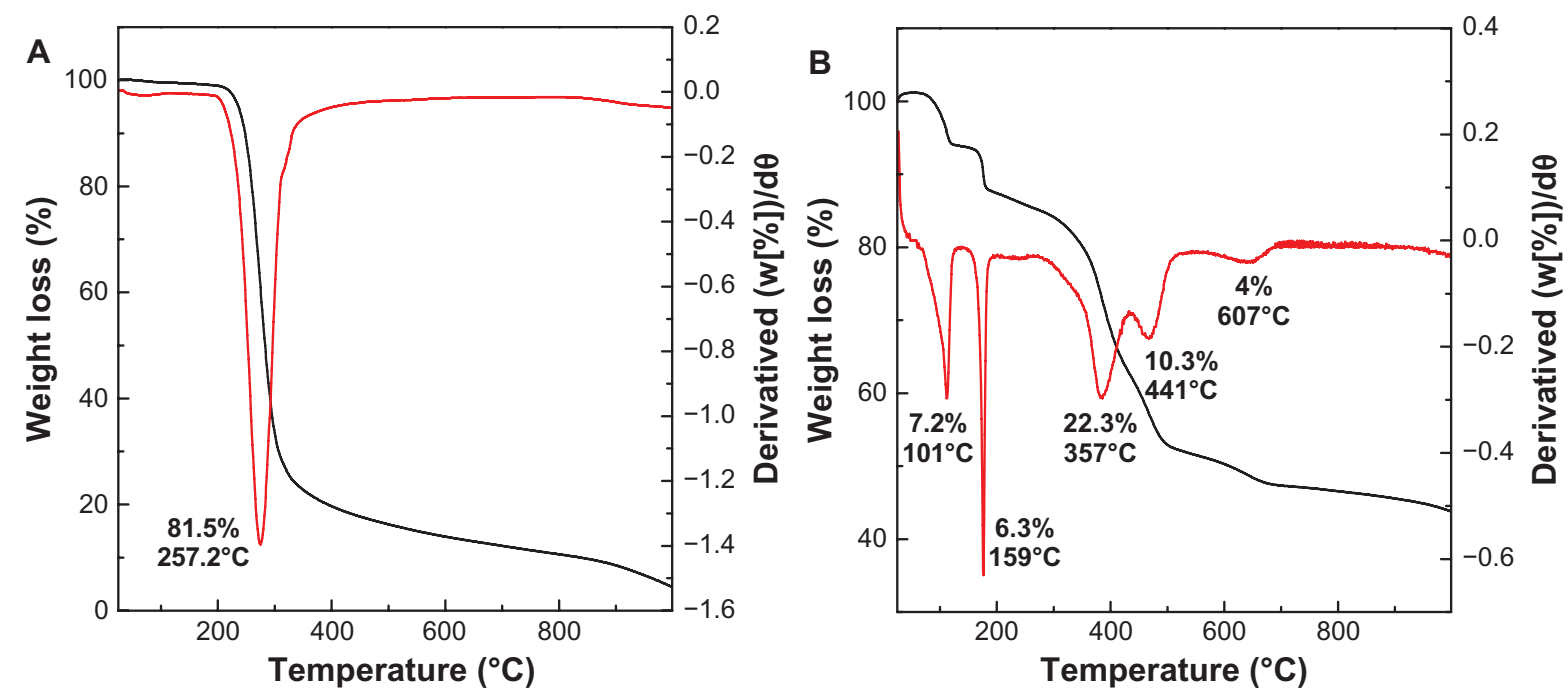

Figure 4 Thermogravimetric and differential thermogravimetric analyses of (A) HA and (B) HAN. Abbreviations: HA, hippuric acid; HAN, hippuric acid nanohybrid.

transitions. In the nanohybrid, HAN, the peaks are shifted to $225 \mathrm{~nm}$ and $285 \mathrm{~nm}$, respectively. The small shift of about $\Delta \lambda_{\max }=2-5 \mathrm{~nm}$, suggests that the positively charged layers of ZLH withdraw electrons of the carbonyl group ${ }^{34}$ into the hippurate anion. These results also confirm that the hippuric acid molecules are stabilized by electrostatic interaction with the positively charged ZLH. In order to calculate the band gap energy of HA, HAN, and zinc oxide, the optical properties of the materials were studied using the Kubelka-Munk equation: ${ }^{35}$

$$
(\mathrm{F} \cdot \mathrm{h} v)^{2}=\mathrm{A}\left(\mathrm{h} v-\mathrm{E}_{\mathrm{g}}\right)
$$

where F is the Kubelka-Munk, $\mathrm{h}$ is Planck's constant, $\mathrm{E}_{\mathrm{g}}$ is the band gap energy in eV. The band gap energy can be obtained by plotting the $(\mathrm{F} \cdot \mathrm{hv})^{2}$ against hv. Using the data obtained from Figure 5B, the band gap energy $\mathrm{E}_{\mathrm{g}}$ for zinc oxide is $3.27 \mathrm{eV}$, showing a typical band gap energy for zinc oxide. ${ }^{36}$ The band gap for HAN is $3.94 \mathrm{eV}$, compared with $3.39 \mathrm{eV}$ for pure hippuric acid.

\section{Surface characterization}

Figure 6A shows the adsorption-desorption isotherms for zinc oxide and HAN. As shown in Figure 6A, the adsorption-desorption isotherm for zinc oxide is Type IV by International Union of Pure and Applied Chemistry classification, showing a mesopore type of material. The adsorbate uptake is slow at the relative pressure range of $0.0-0.9$, after which rapid adsorption can be observed. The optimum uptake is only about $8 \mathrm{~cm}^{3} / \mathrm{g}$, indicating a low capacity for uptake of nitrogen gas.

The isotherm for HAN was not very different from that for zinc oxide, ie, the Type IV isotherm still remained. However, for HAN, the adsorption increased fairly rapidly at low relative pressure in the range at $0.0-0.05$, followed by slow uptake of the adsorbent at a relative pressure of 0.05-0.8. Further increase of the relative pressure to $>0.8$ resulted in rapid adsorption of the absorbent, and reached an optimum peak at $27 \mathrm{~cm}^{3} / \mathrm{g}$. The desorption branch of the hysteresis loop for zinc oxide is much narrower compared with HAN, indicating a different pore texture for the resulting material. As a result of nitrogen adsorption, the surface area of the materials as determined by the BET method is shown in Table 2 . The increase in surface area from $6 \mathrm{~m}^{2} / \mathrm{g}$ for zinc oxide to $12 \mathrm{~m}^{2} / \mathrm{g}$ for HAN is due to a change in the pore texture as a result of formation of the nanohybrid compound, which indicates a decrease in the pore size and an increase in the pore volume.

Table 2 Physicochemical properties of $\mathrm{ZnO}$ and HAN

\begin{tabular}{llllllllll}
\hline Sample & $\mathbf{C} \%$ & $\mathbf{H} \%$ & $\mathbf{N} \%$ & $\begin{array}{l}\mathrm{Zn} \\
(\% \mathbf{w} / \mathbf{w})\end{array}$ & $\begin{array}{l}\text { Anion } \\
(\% \mathbf{w} / \mathbf{w})\end{array}$ & $\begin{array}{l}\text { BET surface } \\
\text { area } \mathbf{~ m}^{2} / \mathbf{g}\end{array}$ & $\begin{array}{l}\text { BJH pore } \\
\text { volume } \mathbf{~ c m}^{3} / \mathbf{g}\end{array}$ & $\begin{array}{l}\text { BET average } \\
\text { pore diameter } \mathbf{A}\end{array}$ & $\begin{array}{l}\text { BJH average } \\
\text { pore diameter } \mathbf{A}\end{array}$ \\
\hline $\mathrm{ZnO}$ & - & - & - & $(80.3)$ & - & 6 & 0.01 & 64 & 111 \\
$\mathrm{HAN}$ & 23.3 & 3.5 & 3.1 & $38.3^{\mathrm{b}}$ & $38.7^{\mathrm{a}}$ & 12 & 0.04 & 107 & 130 \\
\hline
\end{tabular}

Notes: Values in parentheses are theoretical value. ${ }^{a}$ Estimated from CHNS analysis; ${ }^{b}$ estimated from ICP analysis.

Abbreviations: HA, hippuric acid; HAN, hippuric acid nanohybrid; ZnO, zinc oxide; BJH, Barret-Joyner-Halenda; BET, Brunauer, Emmett, and Teller. 

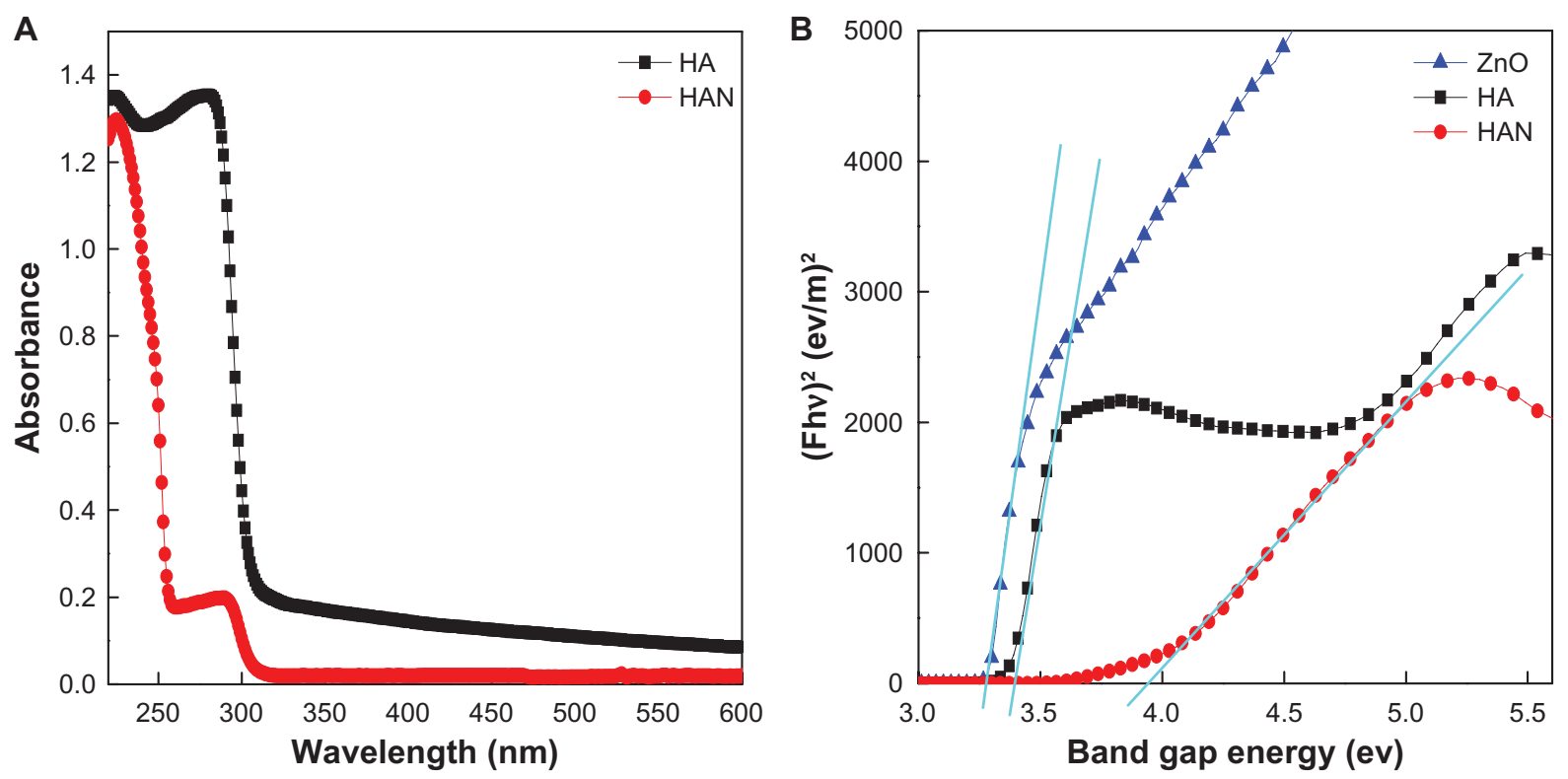

Figure 5 Solid-state ultraviolet-visible spectra of $(\mathbf{A})$ pure $\mathrm{HA}$ and its nanohybrid, HAN and (B) a Kubelka-Munk plot of HA, HAN, and ZnO.

Abbreviations: $\mathrm{HA}$, hippuric acid; $\mathrm{HAN}$, hippuric acid nanohybrid; $\mathrm{ZnO}$, zinc oxide.
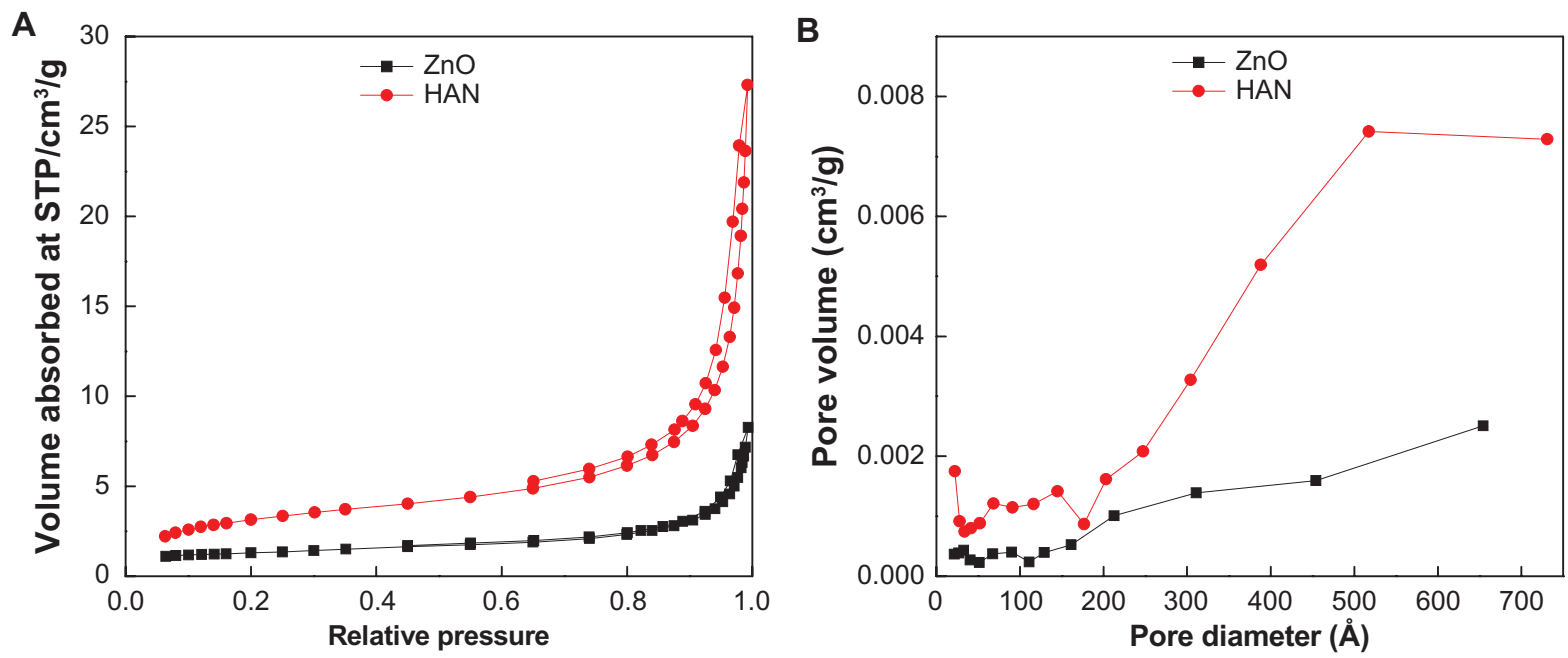

Figure 6 (A) Adsorption-desorption isotherms and (B) BJH pore size distribution for HAN and $\mathrm{ZnO}$. Abbreviations: $\mathrm{BJH}$, Barret-Joyner-Halenda; HAN, hippuric acid nanohybrid; $\mathrm{ZnO}$, zinc oxide.
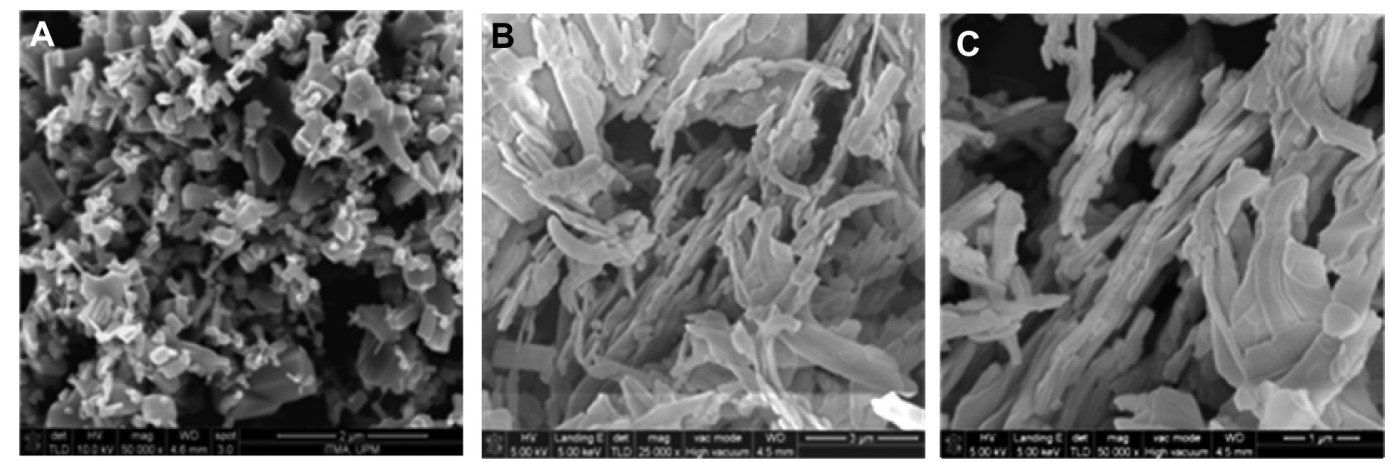

Figure 7 Field emission scanning electron microscopic images of (A) ZnO with 50,000× magnification, (B) HAN with 25,000× magnification and (C) HAN at higher magnification $50,000 \times$.

Abbreviations: $\mathrm{ZnO}$, zinc oxide; $\mathrm{HAN}$, hippuric acid nanohybrid. 
Figure 6B shows plots of the Barret-Joyner-Halenda (BJH) desorption pore size distribution for zinc oxide and HAN. As shown, a single-peak pore size distribution is observed for zinc oxide, centered at around $33 \AA$. On the other hand, the HAN sample showed a single peak at $68 \AA$. The average pore diameter by BET or BJH desorption is shown in Table 2. The average BET pore diameter increased from $64 \AA$ to $107 \AA$ for zinc oxide and HAN, respectively. The BJH desorption pore volume increased from $0.01 \mathrm{~cm}^{3} / \mathrm{g}$ for zinc oxide to $0.04 \mathrm{~cm}^{3} / \mathrm{g}$ for HAN.

The surface morphology of the samples for zinc oxide and HAN studied by field emission scanning electron microscopy are shown in Figure 7. Zinc oxide has a nonuniform granular structure without any specific shape, and with various sizes (Figure 7A). This structure was transformed into a rod-like agglomerated structure with nonuniform size, as shown in Figure $7 \mathrm{~B}$ and $\mathrm{C}$, when intercalation of hippuric acid into the interlayers of ZLH took place.

\section{Release behavior of HA}

The release profiles for hippuric acid from HAN, and the physical mixture of hippuric acid with ZLH in an aqueous solution of $0.08 \mathrm{M} \mathrm{Na}_{2} \mathrm{CO}_{3}$ and phosphate-buffered solution at $\mathrm{pH} 7.4$ and $\mathrm{pH} 4.8$ are shown in Figure 8 . It can be seen (Figure 8D, E, and F) that the physical mixture exposed to $\mathrm{Na}_{2} \mathrm{CO}_{3}$ and phosphate-buffered solution at $\mathrm{pH} 4.8$ and 7.4 released hippuric acid quickly and completely at 16,37, and

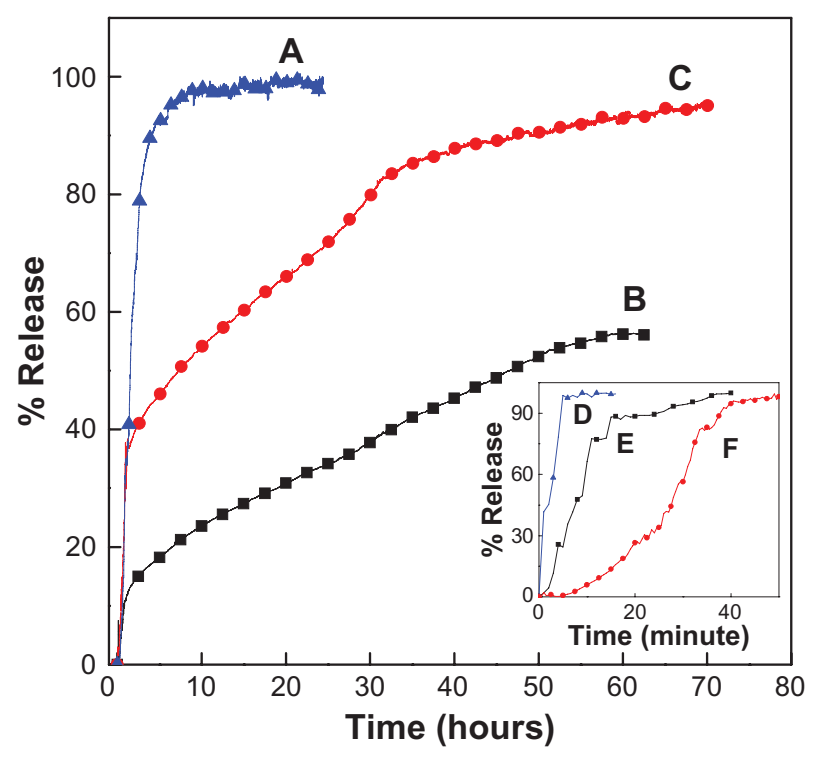

Figure 8 Release profiles of HA from the HAN into (A) phosphate-buffered solution at $\mathrm{pH} 4.8$ and $(\mathbf{B}) \mathrm{pH} 7.4$ and in $(\mathbf{C})$ aqueous solution containing $0.08 \mathrm{M} \mathrm{Na}_{2} \mathrm{CO}_{3}$. Inset shows release profiles of physical mixture of $\mathrm{HA}$ with $\mathrm{ZLH}$ into phosphate-buffered solution at (D) $\mathrm{pH} 4.8$ and $(\mathbf{E}) \mathrm{pH} 7.4$ and $(\mathbf{F})$ aqueous solution of $\mathrm{Na}_{2} \mathrm{CO}_{3}$. Abbreviations: HA, hippuric acid; HAN, hippuric acid nanohybrid; ZLH, zinc-layered hydroxide.
50 minutes for $\mathrm{pH} 4.8, \mathrm{pH} 7.4$, and $\mathrm{Na}_{2} \mathrm{CO}_{3}$, respectively. The release rate of hippuric acid from HAN was obviously very much lower than that from the physical mixture, indicating that the HAN nanohybrid is a potential controlled-release system. This may be due to the electrostatic attraction between the interlayers of ZLH and the hippuric acid molecules that were intercalated.

The hippuric acid release profiles from HAN into $0.08 \mathrm{M}$ $\mathrm{Na}_{2} \mathrm{CO}_{3}$ solution (Figure $8 \mathrm{C}$ ) showed a fast release at the beginning, 39\% for the first 2 hours, followed by a relatively slower stage of $95.7 \%$ for the second 70 hours. The early stage of fast release is possibly attributable to the release of hippuric acid anions from the external part of the nanohybrid structure, and the slow release is due to the exchange of hippuric acid in the internal part of the interlayers with anions in solution.

Figure $8 \mathrm{~A}$ and $\mathrm{B}$ show the release profiles of hippuric acid into phosphate-buffered solution at $\mathrm{pH} 4.8$ and 7.4, respectively. The release rate of hippuric acid from the nanohybrid obviously depends on the $\mathrm{pH}$; the release rate at $\mathrm{pH} 7.4$ is remarkably lower than that at $\mathrm{pH} 4.8$. The percentage release of hippuric acid from the nanohybrid reaches $99.8 \%$ within about 21 hours when exposed to the $\mathrm{pH} 4.8$ solution. When the $\mathrm{pH}$ of the solution was changed to 7.4 , the release rate of hippuric acid was lower, with the time taken for $56.4 \%$ release being 63 hours.

The different release rates at $\mathrm{pH} 4.8$ and 7.4 are possibly due to the different release mechanism for hippuric acid from the inorganic host interlayers. At an acidic $\mathrm{pH}, \mathrm{ZLH}$ may be easily dissolved and the release of the interlayer anions might occur due to the disintegration of the ZLH interlayers together with the ion exchange process. On the other hand, at $\mathrm{pH}$ 7.4, ZLH are more stable, and as a result, release would occur through an anion exchange process involving the intergallery of ZLH.

\section{Release kinetics of hippuric acid from HAN}

In order to study further the release behavior of hippuric acid from HAN, first-order ${ }^{37}$ and pseudo-second order ${ }^{38}$ models were chosen to investigate the release kinetics of this system:

$$
\begin{gathered}
\log \left(M_{t} / M_{o}\right)=-K_{1} t \\
t / q_{t}=1 / k_{2} q_{e}^{2}+t / q_{e}
\end{gathered}
$$

where $M_{o}$ and $M_{t}$ are the amount of hippuric acid between the layers at release time 0 and $\mathrm{t}$, respectively; $\mathrm{k}$ is the cor- 

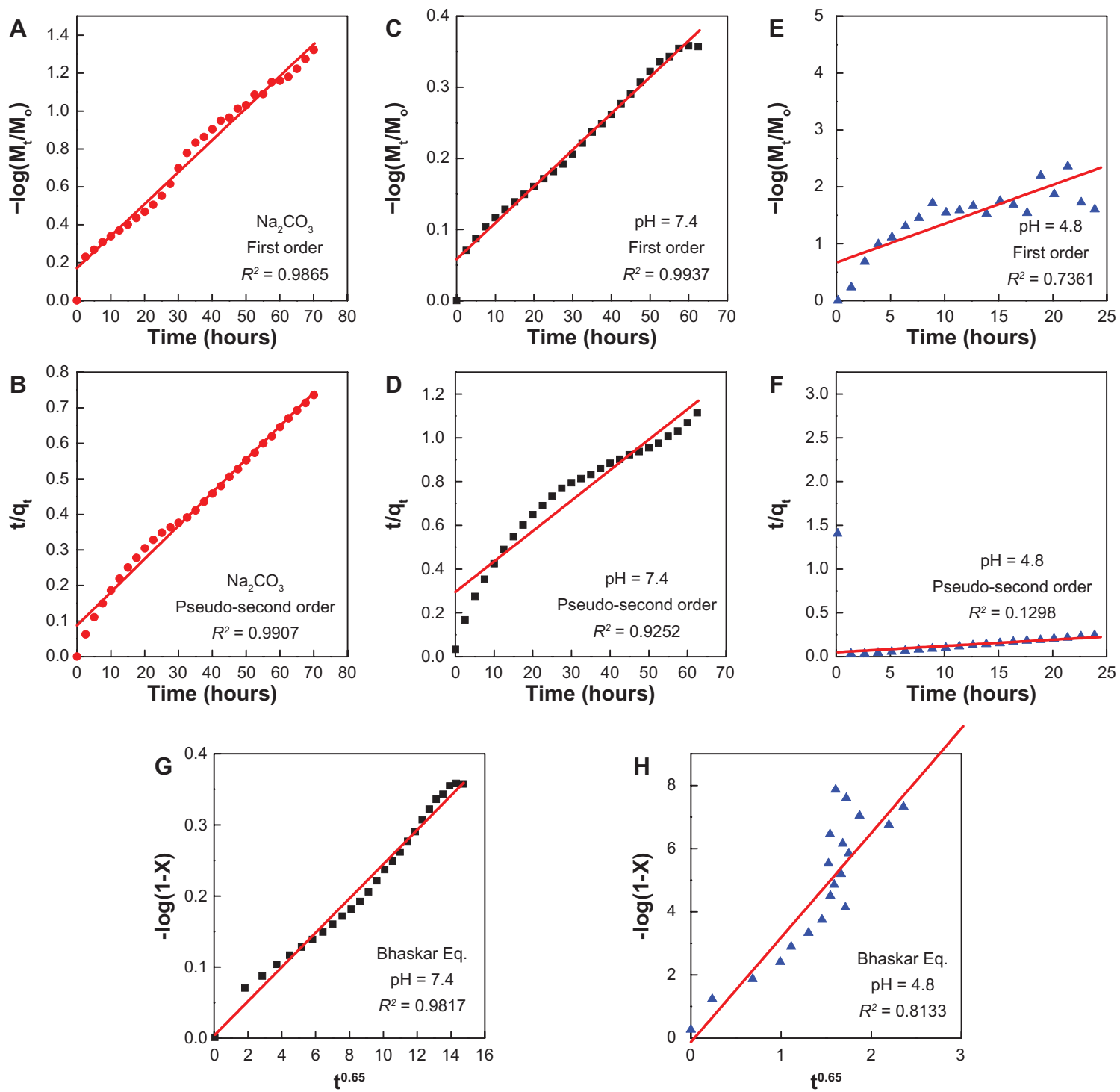

Figure 9 Fitting of the data for $\mathrm{HA}$ release from $\mathrm{HAN}$ into various solutions to the first-order, pseudo-second order kinetics and the $\mathrm{Bhaskar}$ equation for $0.08 \mathrm{M} \mathrm{Na}_{2} \mathrm{CO}_{3}$ (A and B), pH 7.4 (C, D, and $\mathbf{G})$ and pH 4.8 (E, F, and $\mathbf{H})$.

Abbreviations: HA, hippuric acid; HAN, hippuric acid nanohybrid.

responding release rate constant; $\mathrm{q}_{\mathrm{e}}$ and $\mathrm{q}_{\mathrm{t}}$ is the amount released at equilibrium and at time $t$, respectively.

For the last two kinetic models, the fitting results of hippuric acid release data are given in Figure 9 and Table 3. Figure 9B shows that the pseudo-second order kinetic model can be used better to describe the hippuric acid release behavior in $\mathrm{Na}_{2} \mathrm{CO}_{3}$ solution with a correlation coefficient of $\mathrm{R}^{2}=0.9907$ and a rate constant of $0.001 \mathrm{~g} / \mathrm{mg}$.hour. The same kinetic models were also applied to the phosphate-buffered solution at $\mathrm{pH} 7.4$. Figure $9 \mathrm{C}$ shows that

Table 3 Correlation coefficient $\left(r^{2}\right)$, rate constant $(\mathrm{K})$, and half-time $\left(\mathrm{t}_{1 / 2}\right)$ obtained by fitting the data of the release of HA from HAN into $0.08 \mathrm{M} \mathrm{Na}_{2} \mathrm{CO}_{3}$ and in phosphate-buffered solution at $\mathrm{pH} 7.4$ and $\mathrm{pH} 4.8$

\begin{tabular}{|c|c|c|c|c|c|c|}
\hline \multirow{2}{*}{$\begin{array}{l}\text { Aqueous } \\
\text { solution }\end{array}$} & \multirow{2}{*}{$\begin{array}{l}\text { Saturation } \\
\text { release (\%) }\end{array}$} & \multicolumn{3}{|c|}{$r^{2}$} & \multirow[t]{2}{*}{ Rate constant (k) } & \multirow[t]{2}{*}{$\mathbf{t}_{1 / 2}$ (hours) } \\
\hline & & First-order & Pseudo-second order & Bhaskar equation & & \\
\hline $\mathrm{Na}_{2} \mathrm{CO}_{3}$ & 95.7 & 0.9865 & 0.9907 & 0.9802 & $0.00 \mathrm{lg} \mathrm{mg} \cdot \mathrm{g}^{-1, \mathrm{a}}$ & $9.35^{\mathrm{a}}$ \\
\hline $\mathrm{pH} 7.4$ & 56.4 & 0.9937 & 0.9252 & 0.9817 & $0.012 \mathrm{~h}^{-1, \mathrm{~b}}$ & $57.8^{\mathrm{b}}$ \\
\hline $\mathrm{pH} 4.8$ & 99.8 & 0.7361 & 0.1298 & 0.8133 & - & $0.09^{c}$ \\
\hline
\end{tabular}

Notes: a Estimated using pseudo-second order kinetics; 'estimated using first-order kinetics; 'estimated using the Bhaskar equation. 


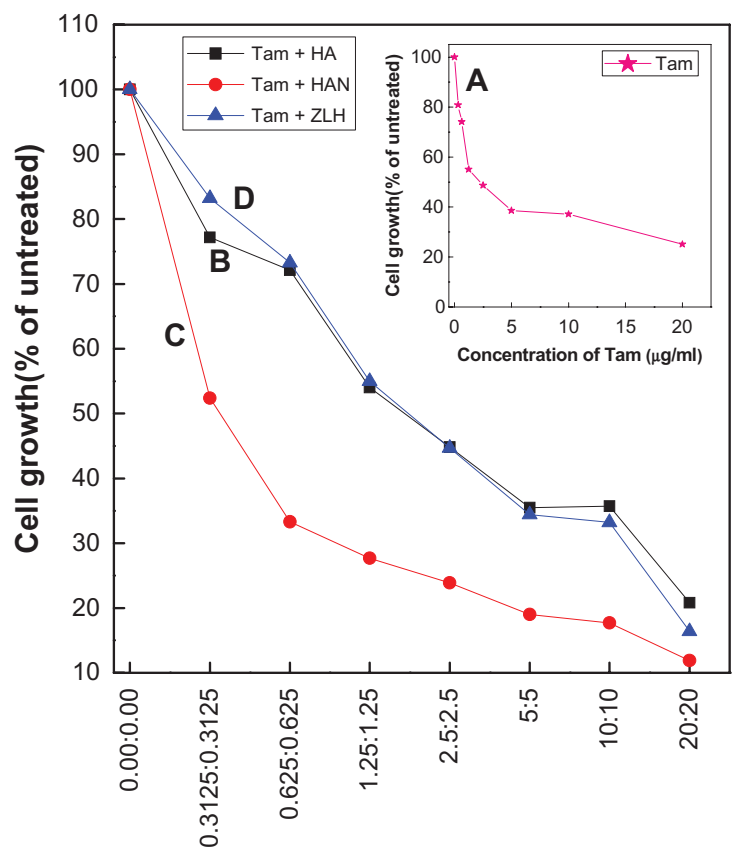

Combination of Tam with HA, HAN and ZLH $(\mu \mathrm{g} / \mathrm{ml})$

Figure 10 MTT assays of HepG2 cells after 72 hours of treatment with combination of tamoxifen with HA (B), HAN (C), and ZLH (D). Inset shows MTT for free tamoxifen (A)

Abbreviations: Tam, tamoxifen; HA, hippuric acid; HAN, hippuric acid nanohybrid; ZLH, zinc-layered hydroxide.

the release profile at $\mathrm{pH} 7.4$ fitted better with the firstorder kinetics model, having a correlation coefficient of $\mathrm{R}^{2}=0.9937$ and a rate constant of 0.012 per hour, and a similar result was obtained for a captopril-layered double hydroxide composite. ${ }^{39}$ The fitting results at $\mathrm{pH} 4.8$ are shown in Figure 9E and F. The release of hippuric acid did not obey either equation, with correlation coefficients of $\mathrm{R}^{2}=0.7361$ and 0.1298 for first-order and pseudo-second order kinetics, respectively.

The drug release could be controlled by diffusion through the layered double hydroxide, or by the diffusion through the solution layer surrounding the particle. The release rate of the drug molecules would be determined by the slower step of these two processes. Bhaskar et $\mathrm{a}^{40}$ developed a simple procedure to establish whether diffusion through the particle was the rate-limiting step:

$$
\ln \left(1-\mathrm{X}_{\mathrm{t}}\right)=-1.59\left(6 / \mathrm{d}_{\mathrm{p}}\right)^{1.3} \mathrm{D}^{0.65} \mathrm{t}^{0.65}
$$

where $d_{p}$ is particle diameter, $D$ is diffusivity, and $X_{t}$ is the release fraction.

This equation suggests that particle diffusion can be fitted to Eq (4), by plotting $\log \left(1-X_{t}\right)$ versus $t^{0.65}$. The good linear relationship indicates that diffusion through the ZLH particles is the rate-limiting step. This method was applied to the experimental data for different $\mathrm{pH}$ values. The results are shown in Figure 9G and H. The correlation coefficient $\left(\mathrm{R}^{2}=0.9817\right)$ was obtained for phosphate-buffered solution at pH 7.4 (Figure 9G), while for $\mathrm{pH} 4.8$ solution, the correlation coefficient was $\mathrm{R}^{2}=0.8133$ (Figure $9 \mathrm{H}$ ).

At $\mathrm{pH} 4.8$, the release of hippuric acid from HAN did not follow the first-order or the Bhaskar equation very well. This phenomenon was presumably due to coeffect behavior, ${ }^{22}$ ie, dissolution of the nanoparticles and ion exchange between the intercalated anions in the interlayer host and phosphate anions in the buffer solution. Table 3 shows the $t_{1 / 2}$ time release of hippuric acid in $\mathrm{Na}_{2} \mathrm{CO}_{3}$ and phosphate-buffered solution at $\mathrm{pH} 7.4$ and 4.8 which was 9.35 hours (for pseudosecond order kinetics), 57.8 hours (for first-order kinetics), and 0.09 hours (for the Bhaskar equation), respectively.

\section{Synergistic effect study of HAN with tamoxifen and antiproliferative assay}

An MTT assay was conducted to observe the effect of tamoxifen on a human liver carcinoma cell line (HepG2), as well as the synergistic potentiating effect of hippuric acid and HAN with tamoxifen (Figure 10). The HepG2 cell line was treated with serial dilutions of tamoxifen from $20 \mu \mathrm{g} / \mathrm{mL}$ to

Table 4 Untreated HepG2 cells during incubation with tamoxifen alone, and combination of tamoxifen with HA, HAN, and ZLH

\begin{tabular}{|c|c|c|c|c|c|}
\hline \multirow{2}{*}{$\begin{array}{l}\text { Concentration } \\
\text { of Tam }(\mu \mathrm{g} / \mathrm{mL})\end{array}$} & \multirow[t]{2}{*}{ Untreated cells (\%) } & \multirow{2}{*}{$\begin{array}{l}\text { Concentration of Tam: } \\
\text { HA or HAN or ZLH } \\
(\mu \mathrm{g} / \mathrm{mL})\end{array}$} & \multicolumn{3}{|c|}{ Untreated cells (\%) } \\
\hline & & & HA & HAN & ZLH \\
\hline 20.0 & 25.1 & $20: 20$ & 20.8 & 11.9 & 16.4 \\
\hline 10.0 & 37.1 & $10: 10$ & 35.7 & 17.7 & 33.2 \\
\hline 5.0 & 38.5 & $5: 5$ & 35.5 & 19.0 & 34.4 \\
\hline 2.5 & 48.6 & $2.5: 2.5$ & 44.8 & 23.9 & 44.7 \\
\hline 1.25 & 55.0 & $1.25: 1.25$ & 54.0 & 27.7 & 55.0 \\
\hline 0.625 & 74.1 & $0.625: 0.625$ & 72.1 & 33.3 & 73.3 \\
\hline 0.3125 & 80.8 & $0.3|25: 0.3| 25$ & 77.2 & 52.4 & 83.2 \\
\hline 0.00 & 100.0 & $0: 0$ & 100.0 & 100.0 & 100.0 \\
\hline
\end{tabular}

Abbreviations: Tam, tamoxifen; HA, hippuric acid; HAN, hippuric acid nanohybrid; ZLH, zinc-layered hydroxide. 


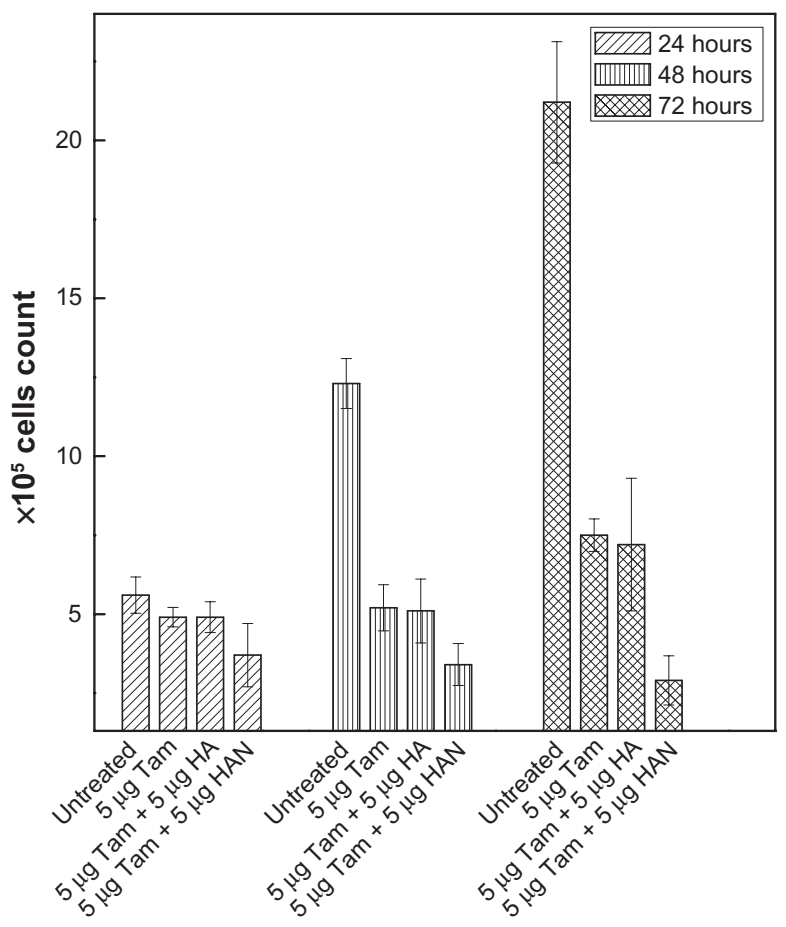

Figure I I Antiproliferative assay of HepG2 cells after, 24, 48 and 72 hours of treatment with free tamoxifen and combination of tamoxifen with HA and with HAN. Abbreviations: Tam, tamoxifen; HA, hippuric acid; HAN, hippuric acid nanohybrid.

$0.3125 \mu \mathrm{g} / \mathrm{mL}$ for 72 hours, and Figure $10 \mathrm{~A}$ shows that the $\mathrm{IC}_{50}$ value is $2.23 \mu \mathrm{g} / \mathrm{mL}$.

To investigate the synergistic potentiating effect of hippuric acid and HAN with tamoxifen toward HepG2 cells, we used a combination of components. The composition of tamoxifen, hippuric acid, and HAN are shown in Table 4 and Figure 10B and $\mathrm{C}$. Table 4 shows that the cytotoxicity of tamoxifen at 0.62 $\mu \mathrm{g} / \mathrm{mL}$ was 2.2-fold greater when HepG2 cells were co-treated with $0.62 \mu \mathrm{g} / \mathrm{mL}$ HAN, whereas co-treatment with hippuric acid only has not increased this toxicity. The combination of tamoxifen with HAN had an approximately 6.4 time lower $\mathrm{IC}_{50}$ $(0.35 \mu \mathrm{g} / \mathrm{mL})$ value than that for those treated with tamoxifen

Table 5 Antiproliferative assay of HepG2 cells after 24, 48 and 72 hours of treatment with free tamoxifen and combination of tamoxifen with $\mathrm{HA}$ and with HAN

\begin{tabular}{llll}
\hline Concentrations & $\begin{array}{l}\times 10^{5} \text { cell } \\
\text { count in } \\
\mathbf{2 4} \text { hours }\end{array}$ & $\begin{array}{l}\times 10^{5} \text { cell } \\
\text { count in } \\
\mathbf{4 8} \text { hours }\end{array}$ & $\begin{array}{l}\times 10^{5} \text { cell } \\
\text { count in } \\
\mathbf{7 2} \text { hours }\end{array}$ \\
\hline Untreated & 5.6 & 12.3 & 21.2 \\
$5 \mu \mathrm{g} \mathrm{Tam}$ & 4.9 & 5.2 & 7.5 \\
$5 \mu \mathrm{g} \mathrm{Tam}+$ & 4.9 & 5.1 & 7.2 \\
$5 \mu \mathrm{g} \mathrm{HA}$ & & & 2.9 \\
$5 \mu \mathrm{g} \mathrm{Tam}+$ & 3.7 & 3.4 & \\
$5 \mu \mathrm{g} \mathrm{HAN}$ & & & \\
\hline
\end{tabular}

Abbreviations: Tam, tamoxifen; HA, hippuric acid; HAN, hippuric acid nanohybrid. only $(2.23 \mu \mathrm{g} / \mathrm{mL})$. MTT results demonstrated that this combination has a higher inhibitory effect on the cell growth of human liver cancer cells when compared to tamoxifen alone. It is worth mentioning that the combination of tamoxifen with ZLH in Figure 10D has an $\mathrm{IC}_{50}$ of $1.86 \mu \mathrm{g} / \mathrm{mL}$.

Figure 11 shows the antiproliferative effect of free tamoxifen and a combination of hippuric acid and HAN on HepG2 cells at various incubation times of 24,48 , and 72 hours. Table 5 shows that the cell counts for untreated HepG2, viable (unstained) cells were 5.6, 12.3, and 21.2 $\left(\times 10^{5}\right)$ cells $/ \mathrm{mL}$ for exposure times of 24,48 , and 72 hours, respectively. As expected, the percentages of cell survival of tamoxifen-treated HepG2 cells were reduced markedly with increase in the exposure time compared to control cells (nontreated cells). The ratio of the viable cell counts for those cells treated by the combination tamoxifen with HAN to untreated cells was sharply reduced from $66 \%$ to $13 \%$ after 24 and 72 hours, respectively, and this reduction in cell growth was higher than that shown for tamoxifen only. Supporting the MTT results, the combination of tamoxifen with HAN showed this inhibitory effect when compared to tamoxifen only. This is because HAN can permeate across the cell membrane much more effectively than hippuric acid alone, and increase the synergistic effect of hippuric acid with tamoxifen in the cells. This indicates the delivery function of nanoparticles.

\section{Conclusion}

This study shows a simple preparation method for a ZLHhippurate nanohybrid, HAN can be formed in an aqueous environment via a one-step method, in which an aqueous suspension of zinc oxide is reacted directly with hippuric acid solution. This method does not need preparation of ZLH in advance, and is followed by an anion exchange step to intercalate the guest hippurate anion into the ZLH interlayers. Therefore, this method is relatively simple and cost-effective. The resulting nanohybrid has a basal spacing of $21.3 \AA$, with $38.7 \%(\mathrm{w} / \mathrm{w})$ loading of the active. Fourier transform infrared results demonstrated an interaction between the negatively charged carboxyl group on hippuric acid and the inorganic interlayers of ZLH. The intercalation process resulted in improved thermal stability of hippuric acid compared with free hippuric acid. The release of hippuric acid anions from HAN was found to occur in a controlled manner, so the resulting material is suitable for a controlled-release formulation. HAN showed synergistic activity with tamoxifen toward the HepG2 cell line, with an $\mathrm{IC}_{50}$ value of 0.35 compared with hippuric acid. 


\section{Acknowledgment}

Funding for this research was provided by a grant from the Ministry of Higher Education of Malaysia (No. 05-03-101035 RUGS [Vot 9199644]).

\section{Disclosure}

The authors report no conflicts of interest in this work.

\section{References}

1. Carlino S. The intercalation of carboxylic acids into layered double hydroxides: a critical evaluation and review of the different methods. Solid State Ionics. 1997;98(1-2):73-84.

2. Brown G, Brindley GW. Crystal Structures of Clay Minerals and their X-ray Identification. London, UK: Mineralogical Society; 1980.

3. Rives V. Layered Double Hydroxides: Present and Future. New York, NY: Nova Science Publishing Inc; 2001.

4. Louer M, Louer D, Grandjean D. [Structural studies of hydroxyl nitrate nickel and zinc I. Structural classification]. Acta Crystallogr B. 1973; 29(8):1696-1703. French.

5. Stahlin W, Oswald HR. The crystal structure of zinc hydroxide nitrate, $\mathrm{Zn}_{5}(\mathrm{OH})_{8}\left(\mathrm{NO}_{3}\right)_{2} \cdot 2 \mathrm{H}_{2} \mathrm{O}$. Acta Crystallogr B. 1970;26(6):860-863.

6. Das S, Roy P, Auddy RG, Mukherjee A. Silymarin nanoparticle prevents paracetamol-induced hepatotoxicity. Int J Nanomedicine. 2011;6: 1291-1301.

7. Liao M, Jan T. A single exposure to iron oxide nanoparticles attenuates antigen-specific antibody production and T-cell reactivity in ovalbuminsensitized BALB/c mice. Int J Nanomedicine. 2011;6:1229-1235.

8. Hussein MZ, Hashim N, Yahaya AH, Zainal Z. Synthesis and characterization of [4-(2,4-dichlorophenoxybutyrate)-zinc layered hydroxide] nanohybrid. Solid State Sci. 2010;12(5):770-775.

9. Marangoni R, Ramos LP, Wypych F. New multifunctional materials obtained by the intercalation of anionic dyes into layered zinc hydroxide nitrate followed by dispersion into poly(vinyl alcohol) (PVA). J Colloid Interface Sci. 2009;330(2):303-309.

10. Marangoni R, Mikowski A, Wypych F. Effect of adsorbed/intercalated anionic dyes into the mechanical properties of PVA: Layered zinc hydroxide nitrate nanocomposites. J Colloid Interface Sci. 2010;351(2):384-391.

11. Miao J, Xue M, Itoh H, Feng Q. Hydrothermal synthesis of layered hydroxide zinc benzoate compounds and their exfoliation reactions. J Mater Chem. 2005;16(5):474-480.

12. Wypych F, Guadalupe Carbajal Arízaga G, Ferreira da Costa Gardolinski JE. Intercalation and functionalization of zinc hydroxide nitrate with mono- and dicarboxylic acids. $J$ Colloid Interface Sci. 2005;283(1):130-138.

13. Rocca E, Caillet C, Mesbah A, Francois M, Steinmetz J. Intercalation in zinc-layered hydroxide: Zinc hydroxyheptanoate used as protective material on zinc. Chem Mater. 2006;18(26):6186-6193.

14. Machado GS, Arízaga GGC, Wypych F, Nakagaki S. Immobilization of anionic metalloporphyrins on zinc hydroxide nitrate and study of an unusual catalytic activity. Journal of Catalysis. 2010;274(2):130-141.

15. Arizaga GG, Gardolinski JE, Schreiner WH, Wypych F. Intercalation of an oxalatooxoniobate complex into layered double hydroxide and layered zinc hydroxide nitrate. J Colloid Interface Sci. 2009; 330(2):352-358

16. Currie M, Macdonald AL. Hippuric acid: a neutron diffraction analysis. J Chem Soc Perkin Trans 2. 1974;2(7):784-787.

17. Hamilton-Miller JM, Brumfitt W. Methenamine and its salts as urinary tract antiseptics: variables affecting the antibacterial activity of formaldehyde, mandelic acid, and hippuric acid in vitro. Invest Urol. 1977;14(4):287-291.
18. Kulcsar G. Synergistic potentiating effect of D (+)-mannose, orotic and hippuric acid sodium salt on selective toxicity of a mixture of 13 substances of the circulatory system in culture for various tumor cell lines. Cancer Detect Prev. 2000;24(5):485-495.

19. Hussein MZ, Bahar FA, Yahaya AH. Synthesis and characterization of hippurate-layered double hydroxide nanohybrid and investigation of its release property. J Iran Chem Soc. 2010;7(42):42-51.

20. Hussein MZ, Al Ali SH, Zainal Z, Hakim MN. Development of antiproliferative nanohybrid compound with controlled release property using ellagic acid as the active agent. Int J Nanomedicine. 2011;6:1373-1383.

21. Nakayama H, Hatakeyama A, Tsuhako M. Encapsulation of nucleotides and DNA into Mg-Al layered double hydroxide. Int J Pharm. 2010;393(1-2):105-112.

22. Zhang H, Zou K, Guo S, Duan X. Nanostructural drug-inorganic clay composites: Structure, thermal property and in vitro release of captopril-intercalated Mg-Al-layered double hydroxides. J Solid State Chem. 2006;179(6):1792-1801.

23. Newman SP, Jones W. Comparative study of some layered hydroxide salts containing exchangeable interlayer anions. J Solid State Chem. 1999;148(1):26-40.

24. Xingfu Z, Zhaolin H, Yiqun F, Su C, Weiping D, Nanping X. Microspheric organization of multilayered $\mathrm{ZnO}$ nanosheets with hierarchically porous structures. J Phys Chem C. 2008;112(31):11722-11728.

25. Refat MS, El-Korashy SA, Ahmed AS. Synthesis and characterization of $\mathrm{Mn}(\mathrm{II}), \mathrm{Au}(\mathrm{III})$ and $\mathrm{Zr}(\mathrm{IV})$ hippurates complexes. Spectrochim Acta A Mol Biomol Spectrosc. 2008;70(4):840-849.

26. Vijayan N, Ramesh Babu R, Gopalakrishnan R, Ramasamy P, Ichimura M, Palanichamy M. Growth of hippuric acid single crystals and their characterisation for NLO applications. J Cryst Growth. 2005;273(3-4):564-571.

27. Allan JR, Dalrymple J. The thermal, spectral and magnetic studies of hippuric acid compounds of cobalt (II), nickel (II), copper (II) and zinc (II) ions. Thermochim Acta. 1991;185(1):83-89.

28. Yasin Y, Ismail NM, Hussein MZ, Aminudin N. Synthesis and characterization of Lawsone-intercalated $\mathrm{ZnAl}$ layered double hydroxides. $J$ Biomed Nanotechnol. 2011;7(3):486-488.

29. Hussein MZB, Long CW. Synthesis of organo-mineral nanohybrid material: indole-2-carboxylate in the lamella of Zn-Al-layered double hydroxide. Mater Chem Phys. 2004;85(2-3):427-431.

30. Brzyska W, Hakim M. Thermal decomposition of Y, La and light lanthanide complexes of hippuric acid. J Therm Anal Calorim. 1988; 34(1):47-53.

31. Refat MS, Teleb SM, Sadeek SA, Khater HM, El-Megharbel SM. Synthesis and characterization of some hippurato rare earth metal complexes. J Korean Chem Soc. 2005;49(3):261-268.

32. Rives V. Characterisation of layered double hydroxides and their decomposition products. Mater Chem Phys. 2002;75(1-3):19-25.

33. Hussein MZB, Ghotbi MY, Yahaya AH, Abd Rahman MZ. Synthesis and characterization of (zinc-layered-gallate) nanohybrid using structural memory effect. Mater Chem Phys. 2009;113(1):491-496.

34. Choy JH, Jung JS, Oh JM, et al. Layered double hydroxide as an efficient drug reservoir for folate derivatives. Biomaterials. 2004;25(15): 3059-3064.

35. Smith RA. Semi Conductors. Volume 2. Cambridge, UK; Cambridge University Press; 1978.

36. Srikant V, Clarke DR. On the optical band gap of zinc oxide. J Appl Phys. 1998;83(10):5447-5452.

37. Murtaza G, Ahmad M, Shahnaz G. Microencapsulation of diclofenac sodium by nonsolvent addition technique. Trop J Pharm Res. 2010; 9(2):187-195

38. Ho YS, Ofomaja AE. Pseudo-second-order model for lead ion sorption from aqueous solutions onto palm kernel fiber. $J$ Hazard Mater. 2006;129(1-3):137-142. 
39. Liu CX, Hou WG, Li Y, Li LF. Synthesis and characterization of camptothecin intercalated into $\mathrm{Mg} / \mathrm{Al}$ layered double hydroxide. Chinese Journal of Chemistry. 2008;26(10):1806-1810.
40. Bhaskar R, Murthy RSR, Miglani BD, Viswanathan K. Novel method to evaluate diffusion controlled release of drug from resinate. Int J Pharm. 1986;28(1):59-66.

\section{Publish your work in this journal}

The International Journal of Nanomedicine is an international, peerreviewed journal focusing on the application of nanotechnology in diagnostics, therapeutics, and drug delivery systems throughou the biomedical field. This journal is indexed on PubMed Central, MedLine, CAS, SciSearch $\AA$, Current Contents ${ } /$ Clinical Medicine,
Journal Citation Reports/Science Edition, EMBase, Scopus and the Elsevier Bibliographic databases. The manuscript management system is completely online and includes a very quick and fair peer-review system, which is all easy to use. Visit http://www.dovepress.com/ testimonials.php to read real quotes from published authors.

Submit your manuscript here: http://www.dovepress.com/international-journal-of-nanomedicine-journal 